\title{
Survival of Mucor piriformis in Soil of Apple Orchards in California
}

\author{
Li-Yun Guo, Postdoctoral Research Associate, Themis J. Michailides, Plant Pathologist, and David P. Morgan, \\ Staff Research Associate, Department of Plant Pathology, University of California, Davis, Kearney Agricultural \\ Center, Parlier 93648
}

\begin{abstract}
Guo, L.-Y., Michailides, T. J., and Morgan, D. P. 1999. Survival of Mucor piriformis in soil of apple orchards in California. Plant Dis. 83:189-193.

Four apple orchards were sampled periodically in 1995 and 1996 to determine the population levels of Mucor piriformis, the causal agent of Mucor rot. The highest population, 119 propagules of M. piriformis per $\mathrm{g}$ of dry soil, occurred during winter. Populations declined during summer and fall and increased again in winter and early spring of the following year. Isolates from soil and apple fruit of these orchards contained,+- , and neuter mating types, with the + being the predominant mating type. Depending on the orchard, up to $27.7 \%$ of apples infected by $M$. piriformis had zygospores developed on them. The time of increase in $M$. piriformis populations corresponded with postharvest drop and decay of apples on the orchard floor. Experiments were carried out to compare changes in $M$. piriformis populations in soil with intact fruit left on the orchard floor, sliced fruit, or after removal of fruit from the orchard. The greatest numbers of $M$. piriformis occurred in soil with apple pieces, followed by soil with intact apples, and the lowest in soil without apples. Results suggest that the best time to sample soils to determine the occurrence of $M$. piriformis in California apple orchards is from January to March, and practices of flail-mowing the orchard floor after harvest may increase population levels of M. piriformis in soil.
\end{abstract}

Additional keywords: Malus domestica, postharvest pathogen

Mucor piriformis A. Fischer is the causal agent of Mucor rot of pome and stone fruit during cold storage (11). Although the optimal growth temperature for this fungus is $20^{\circ} \mathrm{C}$, it can grow and sporulate at 0 to $1^{\circ} \mathrm{C}(5,11)$. Since 1992 , outbreaks of Mucor rot of Granny Smith and Fuji apples have regularly occurred in several packinghouses in the San Joaquin Valley of California. $M$. piriformis is a soilborne pathogen and survives in soil mainly as sporangiospores $(4,6)$. It enters packinghouses in soil adhering to picking bins (8). In Oregon, as many as 8,333 propagules of $M$. piriformis have been recovered per $\mathrm{g}$ of dry soil sampled from harvest bins (8). The fungus also decayed pear fruit, producing primarily sporangiospores and occasionally zygospores $(9,11)$.

Although sporangiospores of $M$. piriformis can survive in soil more than 1 year, their longevity is significantly shortened above $27^{\circ} \mathrm{C}$ (4). A survey of population levels of $M$. piriformis at different soil

Corresponding author: Themis J. Michailides E-mail: themis@uckac.edu

Present address of Li-Yun Guo: Department of Plant Pathology, China Agricultural University, Beijing 100094, P.R. China

Accepted for publication 1 November 1998.

Publication no. D-1998-1214-03R

(C) 1999 The American Phytopathological Society depths in pear orchards in the Hood River Valley, Oregon, revealed that most propagules were in the upper 0 to $5 \mathrm{~cm}$ of soil (12). The populations of $M$. piriformis in pear orchards in Oregon fluctuated annually but regularly showed a substantial increase after harvest (1).

It has been reported that the increase of $M$. piriformis populations in soil was related to the fruit left on the ground $(1,8)$. Insects such as vinegar flies and nitidulid beetles (10), as well as birds (8), can transmit $M$. piriformis from fruit to fruit. Removing fruit left on the ground should prevent the increase in populations of $M$. piriformis in soil. Labor costs, however, make this method impractical for most farmers. Growers want to know if other practices, such as flail-mowing the orchard floor to chop fallen apples, would contribute to disease control. A previous study indicated that $M$. piriformis is a poor competitor compared with other soil saprophytes (5). Therefore, chopping the fallen apples could accelerate decomposition of fruit by other soil microorganisms and consequently reduce $M$. piriformis in soil.

The populations of this fungus have not been studied in the orchards of California's Central Valley, where weather conditions are very different from those in Oregon. Our research investigated the populations of $M$. piriformis in California apple orchards and the effect of various treatments on changes in these populations. Because in $M$. piriformis the mating type plays a significant role in the survival levels of the fungus (7), we also determined the mating type of $M$. piriformis from apple orchards. The presence of $M$. piriformis on fruit left on the orchard floor, the distribution of its mating types, and the natural occurrence of zygospores on fruit were also surveyed. An abstract of the work has been published (2).

\section{MATERIALS AND METHODS}

Populations of $M$. piriformis in orchard soils. Population densities were studied in five plots in four apple orchards located in Madera, Tulare, and Kern counties. In each plot, three soil samples, each composed of 15 bulked subsamples, were collected every other month from Fuji or Granny Smith sites in these orchards. To obtain cross-pollination, apple growers usually plant with Fuji apples (two to four rows) and Granny Smith (one to four rows) alternating. Samples from the same plot were up to six rows apart. A subsample was a soil core collected every four or five trees in one or two rows for each cultivar at a depth of 0 to $5 \mathrm{~cm}$ and 30 to $80 \mathrm{~cm}$ from a tree trunk. Samples were placed in a plastic bag in an ice chest and stored at $5^{\circ} \mathrm{C}$ until processed. After mixing, $50 \mathrm{~g}$ of each sample was placed in a $250-\mathrm{ml}$ bottle with $100 \mathrm{ml}$ of sterile distilled water. The bottles were shaken at low speed in a shaker for $1 \mathrm{~h}$ and left to settle for $1 \mathrm{~min}$. Soil suspension $(0.1 \mathrm{ml})$ was spread on each of five petri plates containing potato dextrose agar (Difco Laboratories, Detroit, MI) amended with $0.01 \%$ tergitol (Nonionic NP-10, Union Carbide Corporation, New York) and acidified with $2.5 \mathrm{ml}$ of a $25 \%$ lactic acid (vol/vol) per liter medium (TAPDA). A preliminary test showed that amending media with tergitol restricts the expansion of colonies without affecting sporulation of $M$. piriformis. On this medium, $M$. piriformis formed restricted colonies with sporangia and sporangiospores after incubating the plates at $20^{\circ} \mathrm{C}$ for $24 \mathrm{~h}$ and at $5^{\circ} \mathrm{C}$ for 7 to 9 days. Each colony was isolated by touching the sporangia with a needle and transferring to acidified potato dextrose agar (APDA). The mating type of each isolate was determined by crossing with + (TJM1514) and (TJM1504) mating types of $M$. piriformis and incubating the plates at $20^{\circ} \mathrm{C}$ for 1 or 2 weeks.

Infection of fruit on the orchard floor. From 17 January to 15 February 1995, 20 apple orchards in California were surveyed 
for the presence of $M$. piriformis on fruit left on the ground. From 200 to 300 apples were examined for each orchard. M. piriformis was identified visually in each orchard by the characteristic sporulation on infected fruit. In 1996 and 1997, 46 to 90 decayed or wounded (partially eaten by birds or rodents) apples left on the floor were collected from four selected orchards, and the frequency of sporulation of $M$. piriformis on fruit was determined after 6 days of incubation at $5^{\circ} \mathrm{C}$. The apples colonized by $M$. piriformis were incubated at $5^{\circ} \mathrm{C}$ for 2 additional weeks. Development of zygospores on these fruit was examined under a dissecting microscope $(\times 20)$ after washing away sporangia and sporangiospores with tap water.

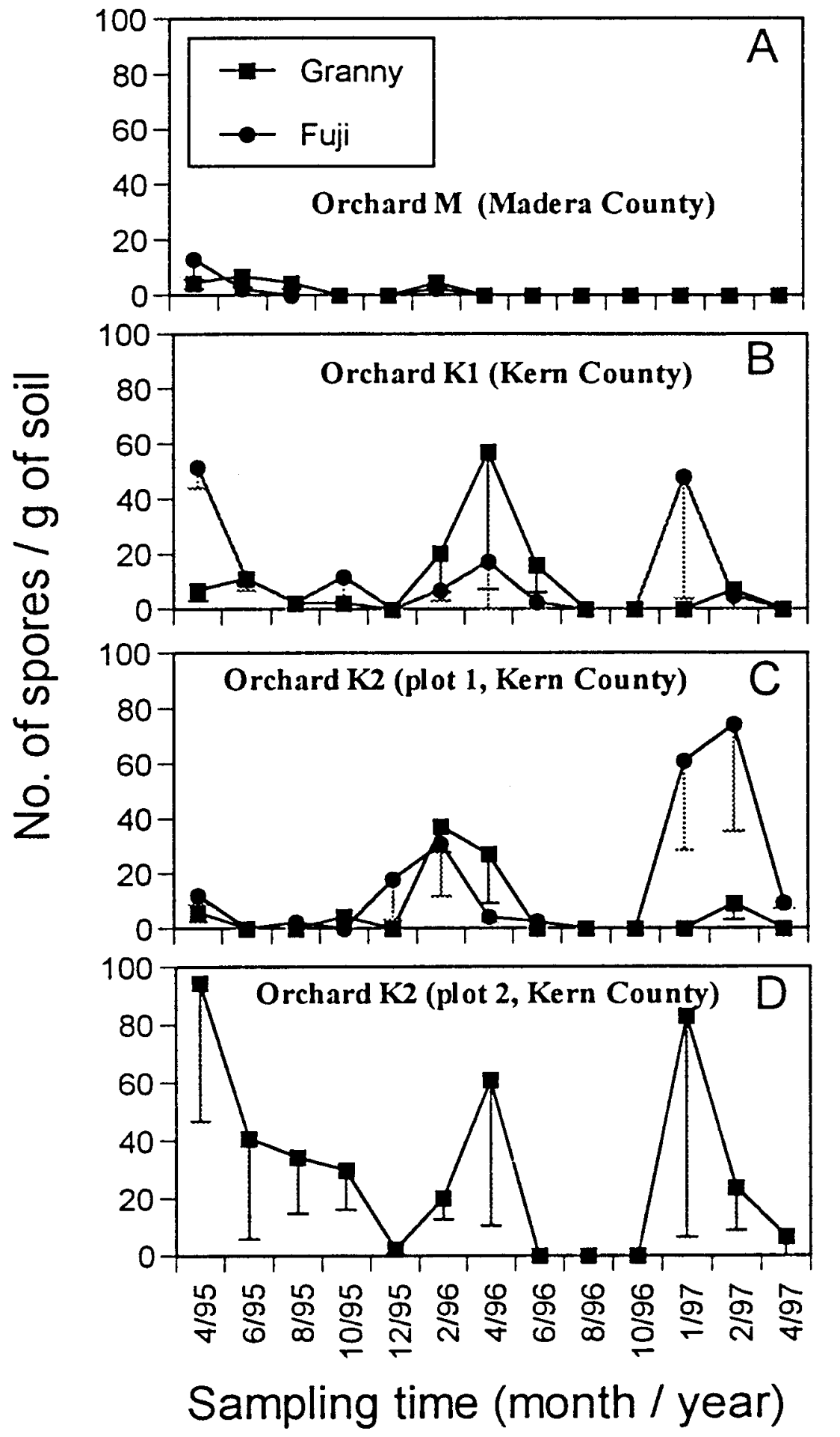

Fig. 1. Population densities of Mucor piriformis in four plots of three apple orchards in San Joaquin Valley of California over a 24-month period. Numbers on x-axis refer to month/year, beginning with April 1995. Each point is the average of three values. (A) Orchard M of Madera County. (B) Orchard K1 of Kern County. (C) Orchard K2 (plot 1) of Kern County. (D) Orchard K2 (plot 2) of Kern County. Bars represent standard error.

Populations of $M$. piriformis in soils with fruit left intact, cut in pieces, or removed. The experiment was initiated on 11 January 1996 and terminated on 11 March 1996 (exp. 1) in a prune field at Kearney Agricultural Center (KAC), California, and repeated on 8 November 1996 to 4 March 1997 (exp. 2) and on 28 January 1997 to 21 March 1997 (exp. 3) in the same field but at different locations. Approximately $75 \mathrm{~kg}$ of soil was collected, sieved through a screen with 6-mm openings, and mixed with $250 \mathrm{ml}$ of a sporangiospore suspension $\left(3 \times 10^{4}\right.$ spores per $\mathrm{ml})$ of $M$. piriformis to obtain an inoculum level of 100 spores per $g$ of soil. Sporangiospores were collected from 1-week-old cultures. Isolates used were TJM1514 in exp. 1 and 2, and TJM1504 in exp. 3. Soil (3.25 kg each) was distributed in 22 wire baskets (26 by 17 by $5 \mathrm{~cm}$ ) that were placed in the field so that the surface of the infested soil was level with the surface of the natural soil. Wounded intact apples (three per basket) were half-buried with the wound in contact with the infested soil to simulate wounded apples left on the orchard floor. The wounds on each apple included a circular area with skin removed by a cork borer (10 $\mathrm{mm}$ diameter), three holes made by a big nail ( $3 \mathrm{~mm}$ wide), and a slash ( $2.5 \mathrm{~cm}$ long) made by a small nail (2 mm wide). Apple pieces (one-eighth slice) from three whole apples (24 pieces per basket) were half-buried in the soil or placed on the soil surface in each basket to simulate the practice of flailing the apples that fall on the orchard floor during and after harvest. Baskets without apples or apple pieces were used as a control treatment. The following March, soil from each basket was collected, mixed well, and stored at 0 to $5^{\circ} \mathrm{C}$ for 1 to 3 days until used. The populations of $M$. piriformis propagules in the soil were determined by the method described earlier; however, the plates were incubated at $20^{\circ} \mathrm{C}$ for $24 \mathrm{~h}$, then at $10^{\circ} \mathrm{C}$ for 5 days. Each experiment was arranged in a completely randomized design, with four replicates in exp. 1 and five replicates in exp. 2 and 3. Analysis of variance was conducted with SAS (Release 6.11 ed., SAS Institute, Cary, NC). Since the means and variance of the data were not independent, logarithmic transformation was applied before analysis. Means between treatments were compared using the least significant difference test at $P=$ 0.01 .

Weather data, including daily precipitation and maximum air (measured at $2 \mathrm{~m}$ height) and soil (measured at $15 \mathrm{~cm}$ depth) temperatures, were obtained from the closest station (CIMIS no. 39) located on KAC.

Determination of mating type of various isolates. Because mating type plays a significant role in the biology of $M$. piriformis (7), the mating type of each isolate was determined by pairing a mass of spo- 
rangiospores with another mass of sporangiospores of (+) tester (ATCC58344 or TJM1514) or (-) tester (ATCC58343 or TJM1504) on APDA medium. Sporangiospore masses were placed $3 \mathrm{~cm}$ apart in small plastic petri plates. After incubation at 9 to $10^{\circ} \mathrm{C}$ for 10 days, isolates forming zygospores with the + tester were designated - mating type and isolates forming zygospores with the - tester were designated + mating type. Isolates that did not form zygospores with either + or - testers were designated neuter (7). Representative samples of neuter isolates were tested for a second time by crossing them again with either + or - mating types of $M$. piriformis.

\section{RESULTS}

Populations of $M$. piriformis in orchard soils. In orchard $\mathrm{T} 1$ of Tulare County, $M$. piriformis was detected only in June 1995 in the Granny Smith apple site (4.6 propagules per $g$ of dry soil) and in February 1997 in the Fuji apple site (119 propagules per $\mathrm{g}$ of dry soil). In orchard $\mathrm{M}$ in Madera County, the populations of $M$. piriformis propagules were low throughout the sampling period (Fig. 1A). In this orchard (due to removal of Fuji trees in September 1996, soil was not sampled from Fuji rows after August 1996), M. piriformis populations did not increase in the plot with Granny Smith apples during the winter of 1996 (Fig. 1A). Apples were removed from the orchard floor at the end of harvest by the grower during these 2 years for the orchard M. In the orchards $\mathrm{K} 1$ and $\mathrm{K} 2$ in Kern County, the population density of $M$. piriformis was high in the spring of 1995, gradually declined during the summer and fall, increased significantly in the winter (December 1995 to January 1996) (Fig. 1B to D), and declined again the following spring. A similar pattern was observed in these orchards in the following year. In orchards $\mathrm{K} 1$ and $\mathrm{K} 2$ of Kern County, the annual cyclic pattern found in the Granny Smith apple site was similar to that of the Fuji apple site (Fig. 1B and C). The highest population density obtained during this 24-month period was 119 propagules per $\mathrm{g}$ of dry soil. Isolates from soil in all four orchards contained both + and - mating types (Table 1). Isolates that did not cross with any of the mating types were also isolated from three of the four orchards. However, when 28 representative neuter isolates were tested 2 weeks later, 27 reacted as + mating type and one reacted as - mating type.

Infection of fruit on the orchard floor. In 1995, a survey of 20 commercial orchards for the presence of $M$. piriformis on fruit showed that in 13 orchards the pathogen was sporulating abundantly on fruit left on the ground. Up to $12 \%$ of fruit in these orchards had sporulation of $M$. piriformis.

In February 1996, sporulation of $M$. piriformis also was observed on fruit left on the ground in orchard T2 of Tulare County. Among 84 decayed apples collected, seven were found with $M$. piriformis after 1 week of storage at 0 to $5^{\circ} \mathrm{C}$ (Table 2). In addition, sporulation of $M$. piriformis was observed on wounds made by birds.

On 22 October 1996, about 1 month after harvest, a survey in orchard $\mathrm{K} 2$, where abundant fruit were found with sporulation of $M$. piriformis in early 1995 , showed no sporulation of $M$. piriformis on decaying fruit on the ground (Table 2). In rows of Fuji apple, many fruit were on the ground, while in rows of Granny Smith, many fruit were left on the trees and few were on the ground. No sporulation of $M$. piriformis was observed on 57 and 55 fruit with soft rot symptoms collected from the ground of these two plots after storage at 0 to $5^{\circ} \mathrm{C}$ for 1 week or 1 month (Table 2). However, on 6 January 1997, many Granny Smith apples were found on the orchard floor. Sporulation of $M$. piriformis was only observed on fruit partially eaten by birds or on fresh wounds made by birds or rodents. In total, 77 Fuji and 147 Granny Smith apples with soft rot symptoms or wounds made by birds and/or rodents were collected from plot 1 and plot 2 of orchard
K2. Approximately $40 \%$ of these fruit developed $M$. piriformis after 6 days of incubation at 0 to $5^{\circ} \mathrm{C}$ (Table 2). Most of the sporulation by $M$. piriformis grew on wounds made by birds or rodents. Twentytwo percent of Granny Smith apples collected from orchard K1 of Kern County had $M$. piriformis after storage. However, $M$. piriformis was not observed on Fuji apples collected the same day from the same orchard (Table 2). After 3 weeks in cold storage, zygospores of $M$. piriformis were observed in a total of 16 fruit collected from K1 and K2 orchards. Zygospores developed mainly on wounds made by birds or rodents. The number of zygospores produced per apple varied from 10 to several thousand.

Both mating types of $M$. piriformis were isolated from infected fruit (Table 3). In orchard K1, the + type predominated (ratio $11: 1$ ), while in orchard $\mathrm{K} 2$, the ratio of + and - mating type isolates was close to $1: 1$. In orchard $\mathrm{K} 2$, a few fruit contained both mating types (Table 3 ).

Populations of $M$. piriformis in soils with fruit left intact, cut in pieces, or removed. Two weeks after initiating the experiments, sporulation of $M$. piriformis was observed on either the apple pieces left

Table 1. Mating type of cultures of Mucor piriformis isolated from soils in apple orchards in California

\begin{tabular}{lcccc}
\hline & \multicolumn{3}{c}{ Mating type $^{\mathbf{a}}$} & $\begin{array}{c}\text { Isolates } \\
\text { Orchard, location }\end{array}$ \\
\cline { 2 - 4 } tested (no.)
\end{tabular}

a Each isolate was crossed with + and - testers individually on acidified potato dextrose agar plates incubated at 9 to $10^{\circ} \mathrm{C}$ for 10 days.

${ }^{b}$ Subsequent mating of selected isolates indicated that isolates were one of the two mating types.

Table 2. Presence of Mucor piriformis on apples left on the orchard floor in California apple orchards

\begin{tabular}{|c|c|c|c|c|c|}
\hline \multirow[b]{2}{*}{$\begin{array}{l}\text { Orchard } \\
\text { Location }\end{array}$} & \multirow[b]{2}{*}{$\begin{array}{c}\text { Date of } \\
\text { collection }\end{array}$} & \multirow[b]{2}{*}{ Cultivar } & \multicolumn{3}{|c|}{ Number of fruit } \\
\hline & & & Collected & $\begin{array}{l}\text { Colonized by } \\
M \text {. piriformis }^{\mathrm{a}}\end{array}$ & $\begin{array}{c}\text { With } \\
\text { zygospores }^{\mathbf{b}}\end{array}$ \\
\hline $\begin{array}{l}\text { T2, } \\
\text { Tulare County }\end{array}$ & 2 Feb 1996 & $\begin{array}{l}\text { Fuji and } \\
\text { Granny Smith }\end{array}$ & 84 & $7(7)^{\mathrm{c}}$ & 0 \\
\hline $\begin{array}{l}\text { K2 (plot } 1) \\
\text { Kern County }\end{array}$ & 22 Oct 1996 & $\begin{array}{l}\text { Fuji and } \\
\text { Granny Smith }\end{array}$ & 57 & 0 & 0 \\
\hline $\begin{array}{l}\text { K2 (plot 2), } \\
\text { Kern County }\end{array}$ & 22 Oct 1996 & Granny Smith & 55 & 0 & 0 \\
\hline $\begin{array}{l}\text { K1, } \\
\text { Kern County }\end{array}$ & 6 Jan 1997 & Fuji & 46 & 0 & 0 \\
\hline $\begin{array}{l}\text { K1, } \\
\text { Kern County }\end{array}$ & 6 Jan 1997 & Granny Smith & 49 & $11(0)$ & 1 \\
\hline $\begin{array}{l}\text { K2 (plot 1) } \\
\text { Kern County }\end{array}$ & 6 Jan 1997 & Fuji & 77 & $18(12)$ & 5 \\
\hline $\begin{array}{l}\text { K2 (plot 1) } \\
\text { Kern County }\end{array}$ & 6 Jan 1997 & Granny Smith & 87 & $28(17)$ & 2 \\
\hline $\begin{array}{l}\text { K2 (plot 2), } \\
\text { Kern County }\end{array}$ & 6 Jan 1997 & Granny Smith & 60 & $44(44)$ & 8 \\
\hline
\end{tabular}

${ }^{a}$ Fruit were examined with a dissecting microscope after holding in cold storage $\left(5^{\circ} \mathrm{C}\right)$ for 6 days.

${ }^{b}$ The development of zygospores on fruit was examined after the fruit were stored at $5^{\circ} \mathrm{C}$ for 3 weeks.

${ }^{c}$ The value in parentheses represents the number of apples with wounds made by birds or rodents. 
on the soil surface or those half buried in infested soil, but there was no sporulation on whole apples. By the end of the experiment, the population density of $M$. piriformis in soil with cut apples was significantly higher than in soil with whole apples or without apples (Fig. 2) In general, more propagules of $M$. piriformis were found in soil with whole apples than soil without apples $(P=0.01)$, although no difference was detected in the first experiment in which there was high variation among the replicates.

In soil with half-buried apple pieces, the population density of $M$. piriformis in exp. 2 was about three times higher than in exp. 1 and exp. 3. In exp. 3, the population density of $M$. piriformis in soil with apple pieces placed on the surface was significantly $(P=0.01)$ lower than that in soil

Table 3. Mating type of cultures of Mucor piriformis isolates from apple collected from the orchard floor in Kern County, California

\begin{tabular}{llcccc}
\hline & & \multirow{3}{c}{$\begin{array}{c}\text { Isolates } \\
\text { Orchard }\end{array}$} & Cultivar & Mating type $\mathbf{a}^{\mathbf{a}}$ \\
\cline { 5 - 6 } Kested (no.) & Granny Smith & 12 & $(+)$ & $(-)$ & $(+)$ and (-) \\
K2 (plot 1) & Fuji & 14 & 4 & 1 & 0 \\
K2 (plot 1) & Granny Smith & 23 & 11 & 9 & 1 \\
K2 (plot 2) & Granny Smith & 30 & 15 & 11 & 0 \\
& Total & 79 & 41 & 33 & 4 \\
\hline
\end{tabular}

a Each isolate was crossed with + and - testers individually on acidified potato dextrose agar plates incubated at 9 to $10^{\circ} \mathrm{C}$ for 10 days.

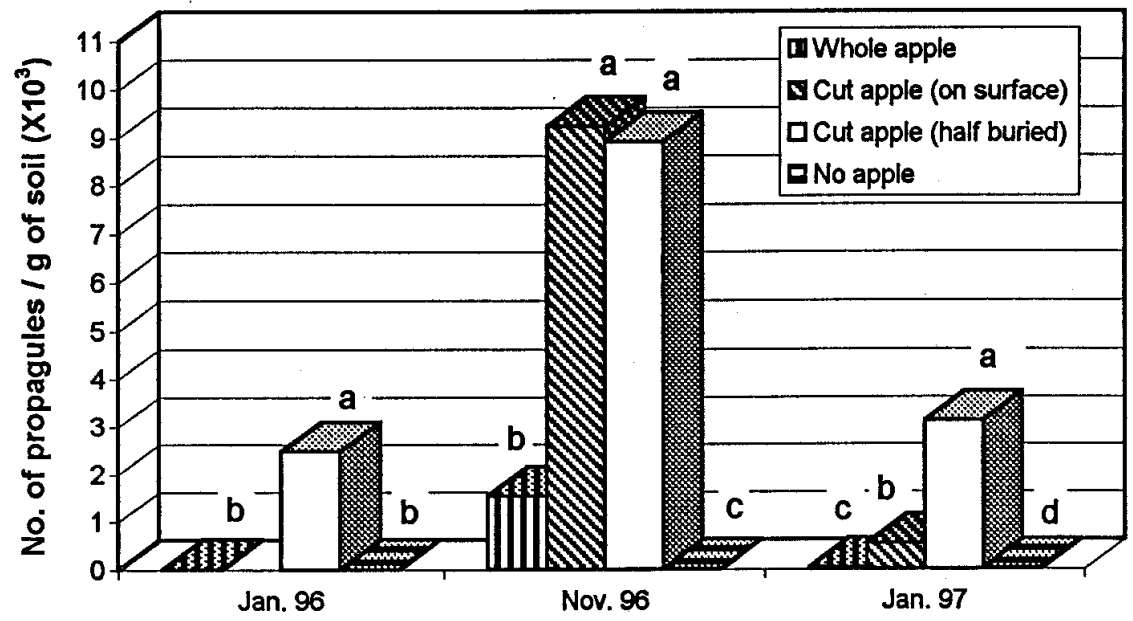

Fig. 2. Population densities of sporangiospores of Mucor piriformis in artificially infested soil with wounded whole apples, cut apples on soil surface, cut apples half-buried in soil, and without apples. Columns topped by different letters within a date are significantly different according to a least significant difference test at $P=0.01$. with apple pieces half-buried. This did not happen in exp. 2.

During exp. 1, from 11 January to 11 March 1996, there were 9 days of precipitation with a total rainfall of $94.5 \mathrm{~mm}$, the air temperature varied between -0.6 and $25.0^{\circ} \mathrm{C}$, and the soil temperature varied between 8 and $16.7^{\circ} \mathrm{C}$. During exp. 2, from 8 November 1996 to 4 March 1997, there were 42 days of precipitation with a total rainfall of $249 \mathrm{~mm}$, the air temperature varied between -2.2 and $22.2^{\circ} \mathrm{C}$, and the soil temperature varied between 8 and $16.7^{\circ} \mathrm{C}$. During exp. 3 , from 28 January to 21 March 1997, there were only 3 days of precipitation with a total of $4.8 \mathrm{~mm}$ rainfall, the air temperature varied between -0.6 and $29.4^{\circ} \mathrm{C}$, and the soil temperature varied between 10 and $19.4^{\circ} \mathrm{C}$. Daily rainfall and maximum air and soil temperature from 8 November 1996 to 21 March 1997 are shown in Figure 3.

\section{DISCUSSION}

This study revealed that populations of $M$. piriformis in California apple orchards fluctuate. Generally, there is an increase in December to March and April, and a decrease afterwards. The time of increase in populations of $M$. piriformis corresponded with the abundance of apples left on the orchard floor after harvest and cool weather conditions. Since $M$. piriformis cannot tolerate high temperatures (its maximal temperature is $27^{\circ} \mathrm{C}$ ) but can grow well at low temperature $\left(0^{\circ} \mathrm{C}\right)$ $(4,6,11)$, high summer temperatures limit the survival of $M$. piriformis, resulting in a decrease of populations in soil. However, the low winter temperatures and the apples left on the orchard floor provide suitable conditions and available substrate for the reproduction of the pathogen, resulting in increased populations.

These results also suggest that the best time for sampling soils to determine the occurrence and populations of $M$. piriformis in California apple orchards is from

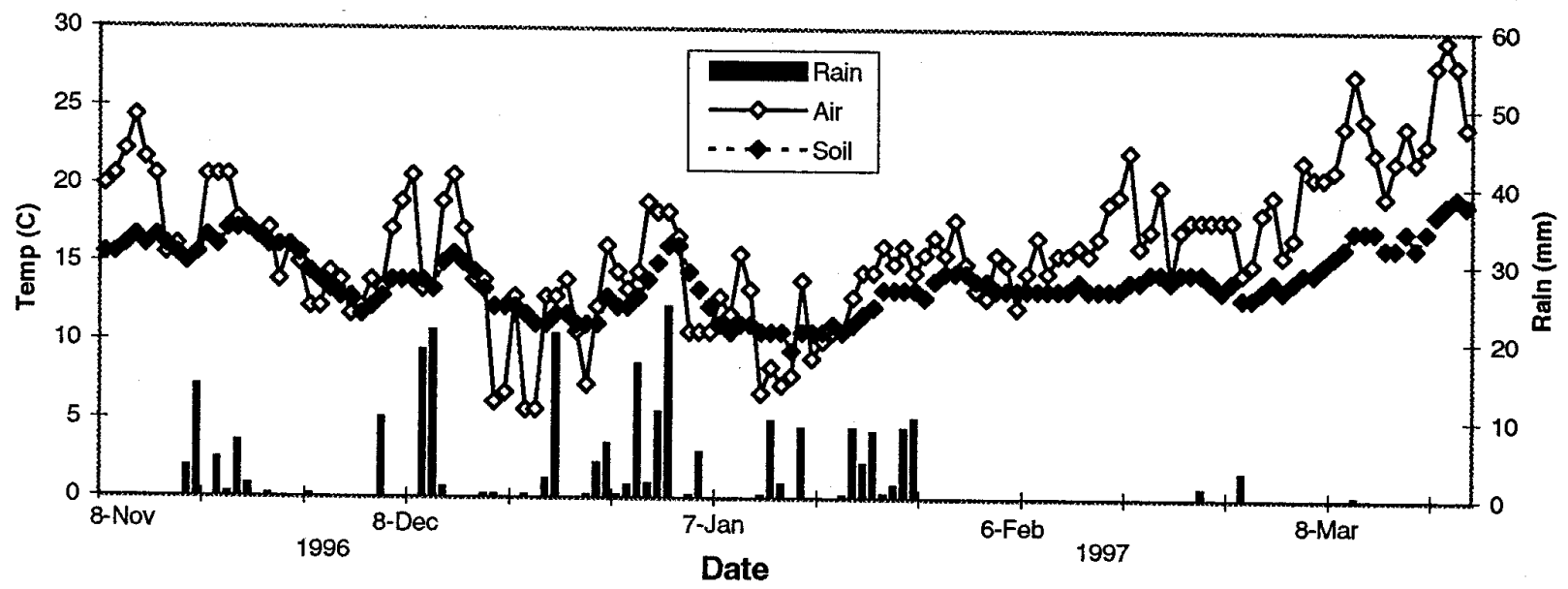

Fig. 3. Daily rainfall and maximum air and soil temperatures at a representative weather station (CIMIS no. 39, Parlier, California) from January 1996 to March 1997. 
January to March. The highest population of $M$. piriformis (119 propagules per $g$ of dry soil) detected during this 2-year period is much lower than that found in pear orchards in Oregon. More than $10^{3}$ sporangiospores (highest of $7 \times 10^{3}$ ) per $\mathrm{cm}^{3}$ of dry soil were detected in Oregon soils (1). The annual cyclic pattern found in California apple orchards is similar to that found in pear orchards in Oregon (1). However, the increase in populations of $M$. piriformis occurred 3 to 4 months after harvest in California, which is 1 to 3 months later than that reported in Oregon pear orchards. This difference may be caused by differences in harvest dates of pears in Oregon and apples in California and weather conditions between the two regions. d'Anjou pears, which suffer the most Mucor rot, are harvested much earlier than apples in California. Furthermore, the summer in California is longer and hotter than in Oregon, and conditions become unfavorable for the survival of $M$. piriformis.

Both + and - mating types have been isolated from soil samples and fruit naturally infected in apple orchards. Similarly, both + and - mating types were detected in pear orchards in Oregon, and zygospores in naturally infested fruit were also recorded (9). Insects such as vinegar flies (Drosophila melanogaster) and nitidulid beetles (Carpophilus hemipterus and $C$. freemani) have been shown to transmit $M$. piriformis in peach and nectarine orchards in California (10). Indeed, these insects can transmit the opposite mating types + and - to the same fruit, resulting in successful mating and production of zygospores (3). Because $M$. piriformis usually initiated from wounds by birds and other animals, it is likely that these animals are involved in the rapid fruit-to-fruit dissemination of $M$. piriformis in apple orchards in California, as was the case with decaying pears in Hood River, Oregon (8). Ecologically, the involvement of these insects and perhaps birds in bringing the two opposite mating types onto the same substrate fruit is of importance, especially since the + mating type predominates over the - type.

The + mating type was the predominant form isolated from apple orchards in the San Joaquin Valley, California. Similarly, the + mating type was the predominant form isolated from pears in Hood River, Oregon (9). Isolating both mating types from apple fruit suggests that zygospores may occur in apple orchards. In fact, depending on the orchard, up to $27.7 \%$ of the apple fruit that had been infected by $M$. piriformis had zygospores. This is the second record of $M$. piriformis zygospores occurring naturally. Although the role in nature of zygospores of $M$. piriformis has not been investigated, because these zygospores can germinate under laboratory (9) and field (3) conditions, zygospores may play a significant role in the survival of the fungus under adverse (hot) conditions.

A greater increase in populations of $M$. piriformis in soil with apple pieces than with whole (intact) apples suggests that flailing after harvest may lead to an increase of soil populations of $M$. piriformis. Apparently, with the same amount of fruit tissue, apple pieces support more reproduction of $M$. piriformis than intact apples. In the field, compared with intact apples, apple pieces decomposed faster and showed more sporulation of $M$. piriformis. Apple pieces have more susceptible surface area exposed than whole apples. This might increase the chance of fruit tissue contacting $M$. piriformis, facilitate sporulation of the fungus, and lead to an increase of population of the pathogen in soil.

The difference between exp. 2 and exp. 3 in regard to population densities of $M$. piriformis in soil with cut apples on the soil surface or half-buried may have resulted from differences in the amount of rainfall and the maximum air temperatures when these experiments were conducted. For exp. 3, there were 4 days that the maximum air temperature was above $27^{\circ} \mathrm{C}$, which is destructive to the survival of $M$. piriformis. In addition, the total rainfall during exp. 3 was only $4.8 \mathrm{~mm}$, much lower than the $249 \mathrm{~mm}$ that occurred during exp. 2. Rain could dislodge sporangiospores of M. piriformis from fruit tissues and carry them into the soil. Since the temperature in soil varied much less than in the air and stayed below $27^{\circ} \mathrm{C}$ during the experiments, $M$. piriformis had a better chance to survive in soil than on the soil surface.
ACKNOWLEDGMENTS

We thank Daniel G. Felts and Brian Ribiero for their help in soil sampling, the apple growers who allowed us to perform these experiments in their orchards and donated fruit, and the California Apple Commission for partial financial support of this project. In addition, this project was partially supported by the International Apple Institute.

\section{LITERATURE CITED}

1. Dobson, R. L., Michailides, T. J., Cervantes, L. A., and Spotts, R. A. 1989. Population dynamics of Mucor piriformis in pear orchard soils as related to decaying pear fruit. Phytopathology 79:657-660.

2. Guo, L. Y., and Michailides, T. J. 1997. Survival of Mucor piriformis in soil of apple orchards in California. (Abstr.) Phytopathology 87:S37.

3. Michailides, T. J., Morgan, D., Spotts, R. A., Beglinger, C., and Odiet, P. A. 1992. Role of nitidulid beetles and vinegar flies in the sexual cycle of Mucor piriformis in tree fruit orchards. Mycologia 84:488-496.

4. Michailides, T. J., and Ogawa, J. M. 1987. Effect of soil temperature and moisture on the survival of Mucor piriformis. Phytopathology 77:251-256.

5. Michailides, T. J., and Ogawa, J. M. 1987. Colonization, sporulation, and persistence of Mucor piriformis in unamended and amended orchard soils. Phytopathology 77:257-261.

6. Michailides, T. J., and Ogawa, J. M. 1989. Effects of high temperatures on the survival and pathogenicity of propagules of Mucor piriformis. Phytopathology 79:547-554.

7. Michailides, T. J., and Spotts, R. A. 1986 Mating types of Mucor piriformis isolated from soil and pear fruit in Oregon orchards (on the life history of Mucor piriformis). Mycologia 78:766-770.

8. Michailides, T. J., and Spotts, R. A. 1986 Factors affecting dispersal of Mucor piriformis in pear orchards and into the packinghouse. Plant Dis. 70:1060-1063.

9. Michailides, T. J., and Spotts, R. A. 1988 Germination of zygospores of Mucor piriformis (on the life history of Mucor piriformis). Mycologia 80:837-844.

10. Michailides, T. J., and Spotts, R. A. 1990. Transmission of Mucor piriformis to fruit of Prunus persica by Carpophilus spp. and Drosophila melanogaster. Plant Dis. 74:287-291.

11. Michailides, T. J., and Spotts, R. A. 1990 Postharvest diseases of pome and stone fruits caused by Mucor piriformis in the Pacific Northwest and California. Plant Dis. 74:537543.

12. Spotts, R. A., and Cervantes, L. A. 1986. Populations of Mucor piriformis in soil of pear orchards in the Hood River Valley of Oregon. Plant Dis. 70:935-937. 